\title{
In search of an Indonesian Islamic cultural identity, 1956-1965
}

\author{
Choirotun Chisaan
}

The emergence of Islamic art and culture organizations is an important aspect of Indonesian cultural history between 1950 and $1965 .{ }^{1}$ These organizations were part of an unprecedented rise in Islamic cultural consciousness in Indonesia at this time, which also produced new genres of Islamic-inspired literature (sastra keagamaan) (Goenawan Mohamad 1969:88) and film (Misbach Yusa Biran 1990:37).

In Goenawan Mohamad's view, there were two factors behind the emergence of this new genre of Islamic literature. The first was a search for identity on the part of Indonesian Islamic writers, and the second was the influence of the political climate of the time (Goenawan Mohamad 1969:89; Kratz 1986:60). Heightened political tensions produced a trend towards factionalism and competition between social groups and organizations, and this meant that the literature of this period was significantly different from that produced by Islamic writers from earlier periods, such as the 1930s novels by the prominent Islamic writer Hamka, who Hairus Salim discusses in his contribution to this volume. In the 1950-1965 period, these two factors identified by Goenawan Mohamad dominated almost all of Indonesian artistic and cultural life, especially that concerned with the expression of an Islamic cultural consciousness.

The unprecedented nature of these developments gave rise to an ongoing debate on the issue of the authenticity of 'Islamic' art and culture in Indonesia. It attracted contributions from scholars based in various Institut Agama Islam Negeri (IAIN, State Islamic Institutes), both those educated in the Middle East and those educated locally, as well as Islamic scholars from other tertiary institu-

1 Thanks for Jennifer Lindsay for sharing with me information and articles about Himpunan Seni Budaja Islam (HSBI, Association for Islamic Arts and Culture). 
tions, ulama (Islamic theologians) and artists, who, as Rusjdi (1965) noted, often recoiled from Koranic verses being recited, probably because it seemed as though art could be justified only in religious terms. This debate reached its high point in 1965, when the first Africa-Asia Islamic Conference (KIAA, Konferensi Islam AfrikaAsia) was staged in Bandung, the same city that had hosted the famous 'Asian-African Conference' of 1955.

The activity surrounding Indonesian Islamic art and culture during the 1950-1965 period led to the formation of two important cultural organizations based on Indonesian interpretations of Islamic thought and practice. These were the Himpunan Seni Budaja Islam (HSBI, Association for Islamic Arts and Culture), formed in 1956, and Lembaga Seniman Budayawan Muslim Indonesia (LESBUMI, Institute of Indonesian Muslim Artists and Cultural Figures ), formed in 1962. HSBI described itself initially as an independent organization, but it was close to the modernist Islamic party MASJUMI (Madjelis Sjura Muslimin Indonesia, Consultative Council of Indonesian Muslims), which was banned by President Soekarno in 1960 (Sidi Gazalba 1977:73). Later, it declared itself to be an organ of the Department of Religion (Departemen Agama). ${ }^{2}$ On the other hand, LESBUMI was officially part of Nahdlatul Ulama (NU), the party of traditionalist Indonesian Muslims that was founded in East Java in 1926.

In this essay, my main focus will be on HSBI, as an extension to my previous research on LESBUMI (Choirotun Chisaan 2008). My concern is not so much with the history of the organization as with the role it played in giving birth to Islamic-based genres of the Indonesian arts and channelling the search for an Islamic identity in Indonesian cultural life during the period under discussion. I will also attempt to describe the organization's role in the cultural politics of this period. However a focus on HSBI does not mean that LESBUMI can be completely disregarded. The two organizations were closely related, and in a political climate characterized by cultural offensives and intense rivalry originating from the growing strength of the Left, they also depended on each other for mutual support and material assistance (Sidi Gazalba 1977:73; Misbach Yusa Biran 2008:162). In this respect, HSBI relied strongly on LESBUMI, because as an organization without the support of a mass base or a particular political party (Misbach Yusa Biran

2 Usmar Ismail 1966. The association with the Department of Religion is consistent with the fact that a number of the organization's founders, such as K.H. Saleh Suaidi, Abdullah Aidid and M. Nur Alian, were employees of the Division of Information on Religion (DJAPENA, Djawatan Penerangan Agama), which was part of the Department's infrastructure. 
2008:145), it depended on the backing that LESBUMI enjoyed through its affiliation with NU. This was not only the case for HSBI, but for all Muslim artists and activists in the cultural field who did not have party political affiliations (Misbach Yusa Biran 2008:162; Goenawan Mohamad 1988:10-1).

LESBUMI's NU connections also meant that it was more widely represented in national bodies set up according to the principles of NASAKOM, Soekarno's ideological formulation that called for a united front of nationalist, religious and communist elements in Indonesian political life. As the guiding principle was 'religion', Islamic organizations with differing approaches found themselves coming together in political alliances that overrode the differences between them. As Misbach Yusa Biran (2008:162) commented, in this climate, 'there was no longer the slightest difference felt between representatives of LESBUMI, representatives of Muhammadiyah, or representatives of al-Wasliah'. ${ }^{3}$ The interests of all Islamic organizations were intimately intertwined, which makes it impossible to discuss the activities of HSBI at this time without also making reference to LESBUMI in various connections.

\section{INDONESIAN ISLAM AS A CITIZEN OF ASIA-AFRICA ISLAM}

In January 1966, translations originally commissioned by President Soekarno in early 1965 of two books appeared on the shelves of Indonesian bookstores. They were Indonesian renditions of two classic studies of Islam by Lothrop Stoddard (1883-1950), The new world of Islam (Dunia baru Islam) and The rising tide of color (Pasang naik kulit berwarna). ${ }^{4}$ As Soekarno remarked in his preface to the

3 'Sedikit pun tidak terasa lagi ada perbedaan antara wakil Lesbumi, wakil Muhammadiyah, wakil al-Wasliah'. Al-Wasliah - also spelt Al-Washliyah, was a religious organization similar in ideology to Nahdlatul Ulama, and based in Medan, North Sumatra.

4 Responsibility for the translations was assigned to the Coordinating Minister for Welfare, Lieutenant-General H.M. Muljadi Djojomartono, who established a publishing committee made up of Prof Dra. Tudjimah, Ismail Jacub, Drs. Sidi Gazalba and Nj. Rochmuljati Hamzah. The translations were based on the original English texts, as well as existing translations into Arabic to assist the committee in its determination of appropriate Islamic terminology. Editorial corrections were undertaken by Drs. Gazali Dunia. Material for supplementary chapters was compiled by Abubakar Atjeh, with suggestions from Prof Dr H. Roeslan Abdulgani, Coordinating Minister for Communication with the People. In its introduction to The new world of Islam, the publishing committee noted that the book had been 'quite warmly received', especially in Islamic circles. Its Arabic translation had become a textbook in Islamic schools and universities right across the Islamic world' (see Stoddard 1966a:5-6). 
Indonesian translations, the two books were already well known in the West. First published in the 1920s, they described the rise of nations of coloured people in Africa-Asia before the outbreak of the Second World War.

The new world of Islam (1921) was particularly concerned with rise of Islam in the countries of the Africa-Asia region. Stoddard suggested that the Islamic resurgence in this region was tied to the influence of the Western model of progress, and recorded also the impact of the reformist spirit initiated by Muhammad bin Abdul Wahab (1703-1787) in Arabia. The purification zeal of the Wahabiyah Movement reached its high point after it came into contact with the political ideals of modern Pan-Islamism and its aspirations towards Muslim solidarity on an international level.

'Islam's solidarity', Stoddard wrote, 'is powerfully buttressed by two of its fundamental institutions: the "Hajj", or pilgrimage to Mecca, and the caliphate.' (Stoddard 1921:38, 1966a:47). The former was particularly important for links between Muslims, and forged the connection between Indonesia and other Islamic nations. However from the middle of the nineteenth century, PanIslamism was responsible for a more modern and organized form of Muslim solidarity, based on new Islamic fraternities such as the Sanusi order that spread rapidly across North Africa in the second half of the nineteenth century, and new proselytizing movements such as those led by political activist and acknowledged founder of Islamic modernity Jamaluddin al-Afghani (1838-1897) (better known as Sayyid Jamāl-al-dīn al-Afghānī), and Syaikh Muhammad Abduh (1849-1905), Egyptian jurist, religious scholar and liberal reformer, also considered founder of Islamic Modernism, who was head of Al-Azhar university in Cairo (Stoddard 1921:52-4, 148; 1966a:52, 153).

Along with the political ideology of Pan-Islamism, this period also saw the rise of Western-style nationalism, which also spread to the non-Western world and resulted in the emergence of movements like 'Young Turkey' and 'Young Egypt'. In the early twentieth century, both these developments came into contact with Russian Bolshevism, with its specific aims, according to Stoddard (1966a:52), of igniting world revolution and destroying Western civilization. In The new world of Islam, Stoddard describes the impact of these developments in detail, but Indonesia is mentioned only in passing. Soekarno, in his 1966 introduction to the Stoddard translations, described Stoddard's treatment of Indonesia as 'lightweight' (tjangkingan), which he attributed to the historical role of imperialism in closing the doors on Indonesia and leaving it unknown in the rest of the world. This, he said, was despite the fact 
that the situation in Indonesia at the time Stoddard was writing was strongly influenced by developments in the rest of the AfricaAsia region. Soekarno's own essays, 'Nasionalisme, Islamisme, Marxisme' from 1926 and 'Indonesianisme dan Pan-Asianisme' of $1928,{ }^{5}$ reflect the influence of these upheavals in the Indonesian context. Soekarno's two essays were spurred by Stoddard's predictions, although unlike Stoddard (1921:273-99; 1966a:268-93), who warned against the dangers that Bolshevism posed to both the West and the East, Soekarno welcomed the combination of the three ideological streams of nationalism, Islamism and Marxism as the basis for an effective weapon against neo-colonialism and imperialism.

It was the 'lightweight' reference to Indonesia in Stoddard's book that made Soekarno recommend the addition of a supplementary chapter to the Indonesian translation of The new world of Islam, which was entitled 'Kebangkitan dunia baru Islam di Indonesia' ('The rise of the new world of Islam in Indonesia'). Considering that the translation was commissioned in 1965, it is clear that this additional chapter was intended to confirm Indonesia's place among the nations of the Africa-Asia region, and to imply that following the rise of Islam in Turkey, Egypt, Palestine and India between 1934 and 1964, Indonesia had also given birth to a revival and renaissance of Islam (Rosihan Anwar 1964:4). At the same time, the chapter was also an expression of Soekarno's optimism about the rise of Islam as one of the three frameworks of the Indonesian revolution and especially the struggle of Indonesian Muslims 'who were enthusiastically carrying out the command of the Head of State to delve into the fire of Islam, to understand this spirit in the struggle of the Islamic umma in all corners of the world'. ${ }^{6}$

The incorporation of Indonesia into 'the new world of Islam', which the translation of Stoddard's work was intended to confirm, can be seen as part of what Soekarno termed 'Indonesia's victories in foreign affairs' ('kemenangan-kemenangan Indonesia jang bersangkut-paut dengan luar negeri') (Sukarno 1965:574). More accurately, these 'victories in foreign affairs' referred to Indonesian achievements in 'Asia-Africa' affairs; events such as the Ministerial Meeting of Africa and Asia II (MMAA), the Konferensi Wartawan AsiaAfrika (KWAA, Conference of Asian and African Journalists), the

\footnotetext{
5 See Sukarno 1964:1-23, 73-7.

6 '[j] ang sedang hangat-hangatnja melaksanakan Komando Kepala Negara untuk menggali apinja Islam, memahami api perdjuangan ummat Islam di seluruh penjuru dunia'. See 'Pengantar kata panitia penerbit' ('Publishing committee’s introduction') in Stoddard 1966a:3.
} 
executive session of the Konferensi Pengarang Asia-Afrika (KPAA, Asia-Africa Writers' Conference) and the Festival Film Asia-Afrika (FFAA, Asia-Africa Film Festival). These 'victories' were all Indonesian government initiatives designed to foster Asia-Africa solidarity and a mobilization of the 'New Emerging Forces' (Sukarno 1965:574). The commission of the translation of Stoddard's book was planned to coincide with the staging of the first Konferensi Islam Afrika-Asia (KIAA, Africa-Asia Islamic Conference) in March 1965, confirming Indonesia's place as a centre of Islamic revival and renaissance equal to the existing examples of Turkey, Egypt, Palestine and India.

AFRICA-ASIA ISLAMIC CONFERENCE

A total of 107 delegates from 33 countries and eight observers from four additional countries were present at the opening of the Africa-Asia Islamic Conference in Bandung on 6 March 1965. As the host nation, Indonesia sent 40 delegates and 21 advisers, representing the full spectrum of the Islamic community in Indonesia at the time. ${ }^{7}$ The Indonesian organizing committee consisted of K.H. Idham Chalid and H.A. Sjaichu (NU), Arudji Kartawinata and Harsono Tjokroaminoto (Partai Sjarikat Islam Indonesia, PSII, Indonesian Islamic Union Party), K.H. Siradjuddin Abbas (Pergerakan Tarbijah Islamijah, PERTI, Islamic Education Movement), K.H.A. Badawi and Prof K.H. Farid Ma'ruf (Muhammadiyah), Wartomo and Agus Sadono (Gabungan Serikat Buruh Islam Indonesia, GASBIINDO, Indonesian Association of Islamic Labour Unions) and H. Zainuddin Dja'far (Al-Washliyah). Assistance was also received from the Department of Foreign Affairs and the Army (Saifuddin Zuhri 1981:654). Originally the conference was scheduled to take place on 17 December 1964/13 Sya'ban 1384, but as this date fell in the lead up to the (fasting) month of Ramadhan, the program was postponed until March 1965. The timing of the official program according to the hijrah calendar was an indication of the conference's significance for the Islamic community, even though it was also an international event.

7 The countries sending delegations were Algeria, Angola, Cambodia, Ceylon (Sri Lanka), Dahomy, Ghana, Guinea, India, Iraq, Japan, Jordan, North Borneo, Kuwait, Lebanon, Liberia, the Maldives, Mauritania, Morocco, Nigeria, Pakistan, Palestine, the Philippines, the People's Republic of China, Senegal, Sudan, Syria, Saudi Arabia, Thailand, Togo, Tunisia, the United Arab Republic (Egypt), the Soviet Union, Yemen and Indonesia. Eight observers represented Afghanistan, Australia, West Germany and Malaysia. See Saifuddin Zuhri 1981:654-5. 


\section{KONPERENSI ISLAM AFRIKA - ASIA mendjebol oldefos dengan segala manifestasinja}

(Gema Islam 3-65 (1 January 1965):6)

One year previously, in June 1964, a preliminary planning conference was held in Jakarta. It was attended by 13 countries as sponsors of the forthcoming main event, including Thailand, Pakistan, Kuwait, Iraq, Saudi Arabia, the United Arab Republic, Tunisia and Morocco. The resolutions of this preliminary conference were described as embodying the 'common resolve of the Africa-Asia Islamic umma to form an Africa-Asia Islamic Organization'. 8 The announcement of the forthcoming conference in the journal Gema Islam noted that this organization would function as 'a forum for the common struggle to unite our forces in order to achieve prosperity and justice under the blessing of Almighty God'. ${ }^{2}$ The preliminary conference also determined the political concepts that were intended to lay down the guiding principles of the main event, stating that 'the basis and aims of the KIAA are to intensify solidarity and cooperation among the umma in the Africa-Asia region in concrete and positive form and in accordance with the spirit of the Ten Bandung Principles'. ${ }^{10}$ Additionally, the conference would aim to discuss 'matters concerned with Islamic Proselytizing (Dakwah), Education (Tarbijah) and culture (tsaqofah)' ${ }^{11}$

The organization of the KIAA itself, according to Saifuddin Zuhri (1981:654), was an initiative of Nahdlatul Ulama, and designed to counter the monopoly over the formation of international movements which hitherto had been exercised by the communists. If Zuhri is correct, then the organization of the con-

8 '[t]ekat bersama antara ummat Islam Afrika-Asia untuk membentuk Organisasi Islami Afrika-Asia'. See 'Konperensi Islam Afrika Asia di Bandung awal Maret 1965', Gema Islam 4-68 (15 February 1965):5.

9 '[w] adah perdjuangan bersama menjatu-padukan kekuatan guna mentjapai kemakmuran dan keadilan jang diridhoi Allah Jang Maha Kuasa'. See 'Konperensi Islam Afrika Asia di Bandung awal Maret 1965', Gema Islam 4-68 (15 February 1965):5.

10 ' $[\mathrm{d}]$ asar dan tudjuan KIAA ialah memperhebat kerdjasama dan solidaritas diantara ummat Islam di negara Afrika-Asia dalam bentuk jang konkrit dan positif, sesuai dengan semangat Dasa Sila Bandung' (Rosihan Anwar 1964:4).

11 '[m] embahas soal2 jang bertalian dengan Da'wah, Tarbijah dan tsaqofah Islamijah' (Rosihan Anwar 1964:4). 
ference should be seen as a manifestation of the intense political rivalry being played out in Indonesia at the time, rather than as an expression of NASAKOM-type 'unity'. In other words, the KIAA was a manifestation of Islamic 'irritation' at the communist domination of foreign policy in relation to the Asia-Africa region. To counter this perceived 'PKI/communist domination', the conference was intended to show that Asia-Africa solidarity and the mobilization of the New Emerging Forces could be fostered on a different basis, that of Islam. It was a political event that would promote Soekarno's thinking about the importance of Asia-Africa unity and solidarity in the fight against imperialism and colonialism, as much as it was a forum for 'cooperation' between Muslim peoples in the Asia-Africa region. The imperialists, Soekarno declared, were in the process assembling an international force to destroy Asia-Africa. This had to be resisted by the peoples of Asia-Africa acting together to avoid the threat of imperialist and colonialist domination. ${ }^{12}$ The question remained, however, as to whether other countries in the Asia-Africa region shared Indonesia's commitment to a NASAKOM-type united front as the way forward in this struggle.

Even though the organization of the conference can be seen as motivated by political interests and ideology, the statement that its guiding principles included the discussion of matters concerned with 'Islamic proselytizing, education and culture' indicates that religious concerns were central to its intended agenda. The resolutions of the preliminary session incorporated a number of nonpolitical items for the agenda of the main conference, among them cooperation among Islamic peoples to strengthen Africa-Asia solidarity in accordance with Islamic teachings; overall coordination of the undertakings of Islamic peoples in the Africa-Asia region in the fields of religion, economics, social affairs, culture and other matters; the formation of an Islamic information bureau; initiatives to estab-

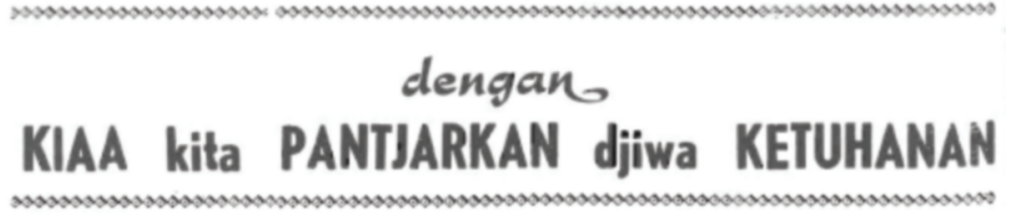

(Gema Islam 3-51 (1 Juni 1964):10)

12 'Presiden Sukarno djelaskan makna revolusi Indonesia dan Ketuhanan Jang Maha Esa Pantjasila', Gema Islam 4-70 (15 March 1965):6-7. 
lish exchange programs in the cultural field; the establishment of an international scholarship program; fellowships and other undertakings to develop Islamic studies in the countries of the Africa-Asia region; a strengthening of the activities of Islamic missions through joint undertakings; the formation of a permanent cooperative body along Islamic principles for the umma of the Africa-Asia region; and the formation of particular organizations for a youth movement, a women's movement and community-oriented undertakings. ${ }^{13}$ For this reason, the Indonesian delegation to the KIAA involved prominent figures drawn from the field of culture and the intelligentsia. Their role was to represent Indonesian interests in discussions of issues concerning the politics of Muslim culture in the wider world, and in the Africa-Asia region in particular.

\section{A DEMONSTRATION OF THE STRENGTH OF THE 'A' COMPONENT OF NAS-A-KOM}

For Indonesian Islamic artists and cultural figures, the KIAA was an event of major significance. It was an opportunity for a high-profile show of strength by Islamic figures in the arts, and the united front presented by various streams of Indonesian Islam coming together in the conference organizing committee highlighted the combined strength of the 'A', or 'Religious', component of the NASAKOM ideology. This assertion of the role of Islamic organizations had begun to emerge clearly in April 1964 when Indonesia hosted the Third Asia-Africa Film Festival. President Soekarno gave his blessing to the organization of the festival, and appointed $\mathrm{Nj}$. Utami Surjadarma as head of the national committee charged with its implementation.

The Third Asia-Africa Film Festival (FFAA III) in Jakarta was a continuation of the first festival held in Tashkent in 1958 and the second festival in Cairo in 1960. From the outset, the Third AsiaAfrica Film Festival of 1964 was dogged by accusations that it was dominated by the 'KOM', or communist faction, through control of the organizing committee by LEKRA (Lembaga Kebudajaan Rakjat, Institute of People's Culture) (Rosihan Anwar 1964:4-5; 2006:273-4, 301). Usmar Ismail, speaking as a representative of the Union of Indonesian Film Companies (PPFI, Persatuan Perusahaan Film Indonesia), declared that the communists had failed to involve representatives of this government-recognized association 
in the organization of the conference. In reply, Sitor Situmorang, the head of the Soekarnoist-oriented Institute of National Culture (LKN, Lembaga Kebudajaan Nasional) who was active in the organization of the festival, declared that Usmar's objections were no more than an attempt to keep from public knowledge his permissive attitude towards the pernicious effects of films originating from the world of the 'Old Established Forces' (OLDEFO) on the peoples of the Africa-Asia region (Rosihan Anwar 2006:273-4). Rosihan Anwar suggests that despite all the bluster at the time, the festival failed to make much of an impact on the cultural life of the capital:

\begin{abstract}
Despite the promotional material surrounding the festival - cinemas only showed films from the festival program - the overall atmosphere was very sedate. I was surprised that the communists made no effort to mobilize their mass organizations to flood into the cinemas showing films from the People's Republic of China, the Soviet Union, North Vietnam and elsewhere. Was it because the people could not be forced to swallow such overly propagandistic films? The fact was that the cinemas showing the festival films were quiet and empty. Even so, the Antara news agency reported that there was a 'gratifying level of interest from the viewing public'. ${ }^{14}$
\end{abstract}

By June of the same year (1964), perhaps with glee that the Asia Africa Film Festival had not been a huge success for the 'KOM' group that had dominated its organization, a sense of excitement was growing about the KIAA conference that was still a year away. Various streams of Islam came together with a sense of one voice, to take part in the planning for the event.

Even though the KIAA was an initiative of Nahdlatul Ulama, the organization of the conference was reported with great enthusiasm in Gema Islam, the magazine published by former MASJUMI party activists and sympathizers which was the voice of HSBI. ${ }^{15}$ The tone of the magazine's response to the conference was expressed in a poem by Zulkabir, published in Gema Islam in June 1964 to coincide with the preparatory meeting:

14 'Kendati gambar-gambar yang menyertai festival - di bioskop hanya diputar film-film dari festival - namun pada umumnya suasana adem ayem belaka. Saya heran juga kaum komunis tidak mengerahkan organisasi massa (ormas) mereka untuk membanjiri bioskop yang memutar film RRT, Uni Soviet, Vietnam Utara dan lain-lain. Apakah karena rakyat tidak dapat dipaksa menelan begitu saja film-film itu yang keterlaluan sekali propagandanya? Kenyataan ialah bioskop-bioskop yang memutar film festival kosong sepi belaka. Toh 'Antara' menyiarkan 'kunjungan penonton memuaskan adanya.' (Rosihan Anwar 2006:301.)

15 See the contribution by Hairus Salim to this volume. 
K.I.A.A.

(Hormatku jang sangat pada P.J.M. Hadji Dr Ir Sukarno)

Pertemuan itu mesra sekali dalam kesamaan tjita

dalam pernjataan suara hakiki dalam lantunannja

di-padang2 luas bakaran matahari dulu lamasekali

setelah mendjalani malamhitam atau nganganja detak djantung

atau tjerita2 pernahnja ia djadi suluh dan terbakar sendiri.

Sekarang ia menetapi wudjud kehadirannja

membenarkan djandji jang pernah diberikan pembebas

dari orang2 jang ingin ambil hak Allah penguasa alam.

Akan dikukuhkan kesetiakawanan antara sesama

sebab itu njawanja sebab untuk itu ia dilahirkan.

Dengan itu penguasaan orang atas orang bangsa atas bangsa

dihantjurkan.

Dengan itu ia berikan sumbangannja pada kemanusiaan sedjagat jang telah disakitkan dihirubirukan.

Pertemuan sesama saudara ini akan mesra sekali

tapi ia penuh dinamika ia mesiu2 jang siap diledakkan

menghanguskan mendjadikan keping2 takberharga itu kezaliman.

Karena memang Islam itu revolusioner

dan sudah sempurna untuk setiap zaman.

(di Indonesia kami telah memanifestasikannja

dalam dasar negara kami Pantja Sila)

Bandung, 1 djuni $1964^{16}$

The Africa-Asia Islamic Conference

(With great respect for H.E. Haji Dr Ir Sukarno)

A gathering full of the warmth of shared ideals, of the expression of the inner truth that rang out

across the hot desert plains - for ages long

after it underwent the darkness of night or a gaping heartbeat

or the stories of a time when it shone like a torch consumed by its own fire.

Now it gives expression to its presence

fulfilling the promise once made - the liberator

from those who would assume the rights of Allah - controller of nature.

Solidarity between brothers will be affirmed

for that it exists, for that it was created. 
Through it the power of people over people, nations over nations, will all be destroyed.

Through it a suffering and confused humanity

will be granted a boon.

This gathering of brothers will be full of warmth but it will also be full of a dynamism set to explode, blowing tyranny into worthless pieces.

Because Islam is indeed revolutionary

and perfectly formed for every age.

(in Indonesia we have manifested its truth

in our state principles of Panca Sila)

Bandung, 1 June 1964

Coverage of the KIAA in Gema Islam lasted from the time planning was begun in March 1964 until after the staging of the conference in March 1965. News of preparations for the event included a report of a goodwill mission by the conference organizing committee to a number of sponsoring countries in March-May 1964. It was led by K.H.A. Sjaichu from NU, and was carried out in conjunction with the performance of the haj. Reports of cultural discussion meetings held in Cipayung in preparation for the conference and a variety of comments and expressions of hope for the conference were also part of Gema Islam's coverage. When the event itself took place, the magazine published comprehensive reports of the proceedings, events taking place outside the official conference, as well as its outcomes, all under a column entitled 'serba-serbi KIAA' ('in and around the KIAA').

The holding of the KIAA was judged to be a rewarding and successful event. It began with a message (amanat) from the President of the Republic of Indonesia, and after the passage of a number of sessions it concluded with a declaration and a set of resolutions relating to cooperation among the umma throughout the world in matters of politics, economics, culture, social affairs, education, proselytizing, international cooperation, world peace and the fate of Muslims in non-Muslim countries. It also issued a series of resolutions concerning the struggle of the Palestinian people and peoples elsewhere who were fighting for national independence (Saifuddin Zuhri 1981:655).

KIAA; THE CULTURAL AND POLITICAL AGENDA

As mentioned above, cultural matters figured alongside political issues on the agenda of the KIAA. Specifically, the conference 
aimed to discuss: 1) developing an Africa-Asia people's culture that did not conflict with Islamic teachings; 2) establishing cultural exchange programs between the Islamic peoples of the Africa-Asia region with a view to strengthening cooperation and Islamic brotherhood; 3) intensifying the application of Islamic teachings and developing a good quality Qur'anic recitation (qiraah) among the peoples of Africa-Asia; 4) encouraging the development of Islamic libraries; 5) promoting the use of spoken Arabic as a language of unity among the umma, alongside the national language of each country; and 6) working towards the establishment of Islamic cultural centres, at both the national and international levels. ${ }^{17}$

In the Indonesian context of the time, questions related to Islamic art and culture could not be separated from political issues, as the KIAA clearly illustrated. The cultural agenda of the conference brought together the full range of Islamic cultural organizations active at the time, working together to contribute to the cultural program and ensure the success of the conference. Apart from HSBI and LESBUMI, the organizations involved were Lembaga Kesenian Islam (LEKSI, Institute of Islamic Arts) which was affiliated with PERTI; Lembaga Kebudajaan Sjarikat Muslimin Indonesia (LAKSMI, Cultural Institute of the Union of Indonesian Muslims) affiliated with PSII; Ikatan Seniman dan Budajawan Muhammadijah (ISBM, Muhammadiyah League of Artists and Cultural Figures) and Ikatan Sardjana Muslim Indonesia (ISMI, League of Indonesian Muslim Graduates). Liaison between these organizations was facilitated in a body named Badan Musjawarah Kebudajaan Islam (BMKI, Council for Deliberations on Islamic Culture), which had been founded in 1963 (Amura 1966:8). Apart from its cultural orientation, this organization was also more overtly political in nature, because its membership comprised both more independent cultural organizations such as HSBI and those clearly affiliated to political parties.

The 1965 KIAA was a demonstration of Muslim unity, both national and international, a unity expressed in political and cultural terms. But it was a unity forged in the particular political situation of Indonesia in 1965, and had come about as the culmination of various organizational alliances in the positioning of Islam in the cultural life of the nation, from the early 1950s to the formation of HSBI in 1956, through to the more militant positioning against the Left of the early 1960s. It is to a discussion of that positioning, moving backwards from the endpoint of the KIAA, that this essay now turns.

17 'Working-paper KIAA; Bidang pendidikan/research, da'wah/missi, penerangan dan kebudajaan (diajukan oleh delegasi Indonesia)', Gema Islam 4-72 (15 April 1965):19-20. 
HSBI belongs to all Muslims, to NU, PSII, PERTI, Muhammadijah, Washlijah and the entire umma. As an organization founded on Religion, HSBI is ready to be a tool in the hands of the Department of Religion, and the Islamic Spiritual Centres of the Army, Navy, Air Force and Police. Furthermore, as an organization of members of a functional group, HSBI as a member of the National Front is ready to take on its duties to the State and the Nation in realizing the ideals of the Indonesian Revolution. ${ }^{18}$

On 12 August 1964, in his capacity as executive head of LESBUMI, Usmar Ismail was asked to give a public lecture on cultural affairs to an association of employees of the Department of Foreign Affairs. Apart from LESBUMI, the association had also issued invitations to two other cultural organizations, LKN and LEKRA. Representing LKN was the organization's Secretary-General, Bagin, while LEKRA was represented by Bachtiar Siagian (Masri S. 1964). Usmar Ismail was unable to attend on the day of the meeting, and the written text of his talk (Usmar Ismail 1964a) was delivered by Naziruddin Naib, director of LESBUMI and head of the distribution office of the National Film Company (Perfini, Perusahaan Film Nasional Indonesia) (Misbach Yusa Biran 2008:93).

In the talk delivered by Naziruddin Naib, Usmar Ismail explained the rationale for LESBUMI's existence alongside other cultural organizations of the time, and described his organization's cultural outlooks. He suggested that as a cultural phenomenon, LESBUMI was similar to LKN and LEKRA, in that they were all mass cultural organizations affiliated to political parties of the time. In LESBUMI's case, its basis was the Pancasila and its guiding principle was Soekarno's Political Manifesto, or MANIPOL. As a cultural organization under the aegis of Nahdlatul Ulama, its foundation was Islamic identity. ${ }^{19}$

18 HSBI adalah milik kaum Muslimin, milik NU, milik PSII, milik PERTI, milik Muhammadijah, milik Washlijah dan semua organisasi Islam serta ummatnja. Dan sebagai organisasi Agama maka HSBI adalah siap mendjadi alat Departemen Agama, PUSROH ISLAM baik AD, AL, AU dan Angkatan Kepolisiannja. Dan selaku satu organisasi Karyawan HSBI sebagai anggauta Front Nasional siap memundak segala tugasnja untuk Negara dan Bangsa dalam mensukseskan tjita2 Revolusi Indonesia. (Junan Helmy Nasution 1963:21.) Note that Junan is also often written as Yunan.

19 Choirotun Chisaan 2008. Usmar's statement that 'as a cultural phenomenon, LESBUMI was similar to LKN and LEKRA' ('fenomena kehadiran Lesbumi tidak berbeda jauh dengan kehadiran LKN dan Lekra') must be seen in the context of the early 1960s, after the launch of MANIPOL-USDEK. At that time, LEKRA had adopted a highly political stance. Even if the existence of LESBUMI was a response to LEKRA, this must be seen in the context of the 1960s, because LESBUMI was formed in 1962. In this it differs from HSBI, which was formed as a response to LEKRA after the 1955 election. 
Usmar's public lecture also outlined LESBUMI's approach to the controversial polemical issue of that time, the question of 'art for art's sake' ('seni untuk seni') or 'art for the People' ('seni untuk rakjat'). LESBUMI, he said, rejected 'art for art's sake' as a manifestation of liberalism in the arts, which implied that the function of art was merely to indulge the desires of human beings as individuals. At the same time, however, LESBUMI also rejected 'art for the People', which, he said, was being loudly bandied about ('dikaokkan secara keras') by certain groups (LEKRA and LKN). ${ }^{20}$ This was especially the case when 'the People' actually referred to the political allies of these particular groups. For LESBUMI, art was a means of showing one's devotion to God..$^{21}$

The cultural viewpoints of LESBUMI outlined in Usmar Ismail's lecture did not differ greatly from those of HSBI. In December 1963 the two organizations had joined with other Islamic cultural groups to hold a meeting in Jakarta under the title National Deliberation on the Development of Islamic Morals and Art (Musjawarah Nasional Pembangunan Moral dan Seni Islam). The chair and organizing secretary of the meeting were Djamaluddin Malik and Usmar Ismail from LESBUMI. ${ }^{22}$ The meeting was judged a success, both from the point of view of the discussion itself and its contribution to the unity of Indonesian cultural organizations based on Islam. It resulted in the establishment of the Council for Deliberations on Islamic Culture (BMKI), under the leadership of Djamaluddin Malik, which was to play an important role in the success of the cultural program of the KIAA.

HSBI: A PIONEER IN THE DEVELOPMENT OF ISLAMIC CULTURE

Long before the emergence of LESBUMI, HSBI was a prominent organization in the area of Indonesian national culture. It was established in Jakarta on 24 September 1956, and like LEKRA, declared

20 For the Islamic view of 'art for art's sake' and 'art for the People', see Sidi Gazalba 1977:53-4.

21 In the title of the lecture (Usmar Ismail 1964a), the date of the meeting is given as ' 7 August 1964'. Originally scheduled for that date, the meeting was postponed until 12 August because the LEKRA representative was unable to attend. On 12 August, Usmar Ismail had another engagement in Bandung.

22 A report in Gema Islam 3-45 (1 January 1964) stated that the meeting had been organized by HSBI and the Council of Islamic Artists and Cultural Figures (MASBI, Madjelis Seniman Budajawan Islam). Subsequently, in Gema Islam 3-46 (15 January 1964):20 a correction was issued, confirming that the organization had involved HSBI, MASBI, LESBUMI, LEKSI, and the cultural association of the PSII. 
itself free of any party political affiliation..$^{23}$ From the beginning, its main aim was to contest LEKRA influence in the wake of the PKI's strong showing in the 1955 general elections. Kratz (1986:70) notes that in 1956, LEKRA issued its revised manifesto, Mukadimah, which was originally drafted in $1950 .{ }^{24}$ According to Kratz, LEKRA's use of the Arabic term for the title of its manifesto posed a challenge to Muslim artists and cultural figures of every kind.

It is clear that HSBI, like LESBUMI, came into existence under the influence of external circumstances, specifically in response to the close relationship between LEKRA and the PKI in matters of culture. By the time of LESBUMI, this relationship had become much more of a threat, because of the influence the PKI enjoyed under the protection of Soekarno in the early 1960s. Together with NU and the Partai Nasional Indonesia (PNI, Indonesian National Party) the PKI was one of the pillars of Soekarno's united front of nationalist, religious and communist forces, a political mechanism that actually heightened tension and competition between the three groups, rather than creating unity between them. The intimacy of the relationship between LEKRA and the PKI was perceived as a threat not only by the Muslim artists and cultural figures associated with HSBI and LESBUMI, but also by those who, in Goenawan Mohammad's words (1988:11), were 'non-party' in their affiliations.

A different explanation for the emergence of HSBI is offered by Nuhrison M. Nuh in his study of the history and role of the organization. Nuh suggests that the impetus for the formation of HSBI came from H. Abdullah Aidid, head of the Division of Information on Religion in the Ministry of Religion (Djawatan Penerangan Agama, Kementerian Agama RI), who wanted to establish an Islamic organization active in the field of art and culture: $:^{25}$

During the Asia-Africa conference in Bandung in 1955, he and a number of delegates from Islamic countries listened to a broadcast of traditional music on Indonesian State Radio (RRI, Radio Republik Indonesia). It attracted their attention, and when he returned from the conference, he instructed M. Nur Alian, then head of the

23 For a statement of the relationship between LEKRA and the PKI, see for example Kusni 2005:53, footnote 13 .

24 The revised Mukadimah of 1955 was published in Zaman Baru 3 (3-6-1956). See Zaini 1957:47-8, footnote 15 .

25 Most of those associated with the establishment of HSBI were from the Ministry of Religion, in particular the Division of Information on Religion. They included K.H.M. Saleh Suaidi, H.M. Arif Lubis, M. Nur Alian, H. Mas'uddin Noor, R.H.O. Hudaja, Ibu Djamari Amin, Zainal Abidin Harahap. C. Asror and M. Saad (Nuhrison M. Nuh 1984:25). 
culture section of the Division of Information on Religion, to think about the possibility of forming an organization or an institute to disseminate information on religion in the field of art and culture. When the association came into being, its instigator, H. Abdullah Maidid was serving as Indonesian chargé d'affaires in Jordan. ${ }^{26}$

Thus, in addition to being a response to LEKRA, HSBI was conceived as an important element in Islamic life in Indonesia, reflecting Hamka's view (1962:12) that Islamic culture was an integral part of life itself. The future of Islam would be determined by the strength of its culture. In Hamka's terminology, HSBI stood at a cultural crossroads with Hinduism, Christianity, the West, and the atheism of the left. To strengthen its position at this crossroads, and in reaction to concern about the lack of cohesion between Islamic groups, the HSBI, in its first National Conference (Muktamar I) in January 1961, took the important decision to establish the Council of Islamic Artists and Cultural Figures (Madjelis Seniman Budajawan Islam) known by its acronym MASBI. This Council was to be made up of ulama without regard to their political positions, along with other scholars and intellectuals with Islamic outlooks, and its function was to discuss various matters concerning the arts and Islamic culture in Indonesia. The HSBI conference directive stated that as soon as possible after the formation of MASBI (to be headed by Hamka), a meeting was to be held between the MASBI members and other Muslim artists and cultural figures, including those affiliated to HSBI.

This meeting, known as the Musjawarah Seniman Budajawan Islam (Deliberation of Islamic Artists and Cultural Figures) took place in December 1961. On the closing night, Hamka, speaking as head of MASBI, described the situation surrounding the establishment of HSBI:

In the upheavals surrounding the development of our nation, it is clear that there has been a struggle for influence between Hindu culture and Western culture. At the same time, Christianity, which

26 Pada tahun 1955 tatkala ia mengikuti konperensi Asia Afrika di Bandung ia bersama delegasi dari negara-negara Islam mendengarkan langen suara yang disiarkan oleh RRI Jakarta. Hal itu menarik mereka, untuk itu setelah kembalinya ia dari mengikuti konperensi itu memerintahkan M. Nur Alian, yang pada waktu menjabat kepala seksi kebudayaan pada Jawatan Penerangan Agama, untuk memikirkan membentuk suatu organisasi atau lembaga yang bergerak dibidang penyuluhan agama dibidang seni budaya. Ketika himpunan ini lahir pemerakarsanya H. Abdullah Aidid sudah berada di Yordania, menjadi kuasa usaha RI disana (Nuhrison M. Nuh 1984:24-5). 
has lost much of its attraction in its countries of origin, has gone in search of new markets in the East. And on the extreme left comes a culture of those who do not believe in the existence of God. They too enter the fray with a militant stance. ${ }^{27}$

When it was formed in 1956, HSBI not only faced the perceived threat of the ascendancy of the PKI with its cultural underpinning in LEKRA, but also a generally cynical attitude towards art and culture in the Indonesian Islamic community. This dual challenge meant that from its inception, HSBI looked to the Department of Religion for official support. It was for this reason that it made K.H. Mohammad Iljas its major sponsor. ${ }^{28}$ In fact, according to HSBI's head, Junan Helmy Nasution, HSBI was entirely K.H. Mohammad Iljas's idea, during his term as Minister of Religion as a member of Nahdlatul Ulama (Junan Helmy Nasution 1963:20). The social and political conditions of the time are captured in the words of Haji Amura:

The consciousness of the younger generation of Muslims acquired tangible form with the formation of HSBI on 24 September 1956 with Minister of Religion K.H. Moh. Iljas as its major sponsor. Several years previously, the formation of an Indonesian Islamic Cultural Congress (BKKII, Badan Kongres Kebudajaan Islam Indonesia) had been canvassed, as a challenge to the efforts of LEKRA/ PKI to control the cultural movement in our homeland. Unfortunately, the BKKII never evolved into anything, as it had a head, but no feet. A cultural movement cannot be constructed from above;

27 Didalam pergolakan pembinaan dan pembangunan bangsa sekarang ini djelas benar perebutan lapangan pengaruh diantara Kebudajaan Hindu dengan Kebudajaan Barat itu. Dalam pada itu muntjul pula Kebudajaan Keristen jang ditanahnja sendiri telah kehilangan daja, lalu mentjari pasaran kembali ke Timur. Dan disebelah kiri sekali datanglah Kebudajaan kaum jang tidak mempertjajai Tuhan. Mereka masuk dengan tjara jang militan pula (Hamka 1962:12).

28 K.H. Mohammad Iljas (1911-1970) was Minister of Religion in the cabinets of Burhanuddin Harahap (12 August 1955-19 January 1956), Ali-Roem-Idham (20 March 1956-9 April 1957) and Djuanda (9 April 1957-10 July 1959). In building and developing his department, he had a reputation for being able to stand above all competing groups, and among all NU Ministers of Religion he alone was not implicated in NU attempts to gain control over the department. As a result, his loyalty to the organization was questioned. He published two books dealing with Marxism and atheism, Bagaimana pandangan Marxisme terhadap agama dan pandangan agama terhadap Marxisme (The Marxist view of religion and the religious view of Marxism) (Jakarta: Endang, 1967) and Bahaja atheisme terhadap keamanan sila Ketuhanan Jang Maha Esa (The danger to the principle of One Omnipotent God posed by atheism) (Jakarta: Pembina, 1968). See Masdar F. Mas'udi and Syafiq Hasyim 1998. 
it has to be organized from below. In contrast to the BKKII, HSBI grew from below, with its feet formed before the head. ${ }^{29}$

PROPAGATING THE FAITH AND SERVING THE REVOLUTION WITH ART AND CULTURE

In the years following its establishment, HSBI limited its cultural activities to the fields of literature and especially drama, which involved both indoor and open-air performances (Amura 1964:19) as well as radio and television broadcasts (Nuhrison M. Nuh 1984:28). This focus on literature and drama was designed to overcome the reluctance of Indonesian Muslims to make use of art as a channel for proselytizing, in the light of past controversies. Memories of the events that followed Bahrum Rangkuti's 1949 dramatization for radio, Sinar memantjar dari Djabal An-Nur (The radiance that shines from the Mountain of Light), were still fresh in the minds of many. The broadcast had elicited a strong negative reaction among some Muslim groups because as a dramatization of the life of the Prophet Muhammad it could be seen as a violation of Islamic prohibitions on representation. As the author of the story on which the radio play was based, Bahrum Rangkuti (who is discussed further by Hairus Salim in his contribution to this volume) was regarded as insufficiently attuned to the sensitivity of Indonesian Muslims towards 'innovations' touching on religious concerns. The same was true of the controversy that surrounded A.A. Navis's 1955 short story, Robohnja surau kami (The collapse of our prayer house), set in a traditional Islamic boarding school in West Sumatra. Since it used satire as a means of raising the issue of fatalism in religious life, it provoked the same reaction as Bahrum Rangkuti's radio play, fierce opposition from within the Indonesian umma itself. ${ }^{30}$

29 Kesadaran angkatan muda Islam itu mendjadi kenjataan dengan dibentuknja suatu organisasi jang diberi nama Himpunan Seni Budaja Islam (HSBI) pada tanggal 24 September 1956 dengan sponsor utamanja K.H. Moh. Iljas, jang ketika itu mendjabat sebagai Menteri Agama. Beberapa tahun sebelumnja telah pernah ditjetuskan idee pembentukan Badan Kongres Kebudajaan Islam Indonesia (BKKII) sebagai tantangan terhadap usaha Lekra/PKI jang hendak mendominasi gerakan kebudajaan ditanah air kita ini. Hanja sajang, BKKII tidak sampai berkembang, karena ia mempunjai kepala dan tidak mempunjai kaki. Gerakan kebudajaan tidaklah dapat disusun dari atas, tetapi lebih penting diatur dari bawah. Berlainan dari BKKII, HSBI ditimbulkan dari bawah, disusun dari kaki terlebih dahulu (Amura 1966:7).

30 Navis discussed this controversy in Abrar Yusra 1994:76-88. Although Abrar Yusra is listed as the author, he is more correctly the 'editor'. The book contains Navis's autobiography together with articles about him and his works. Pages 76-88 deal with the article titled 'Catatan kaki tentang cerpen 'Robohnya surau kami'. 
In his Pandangan Islam tentang kesenian (Islamic views on art) (1977), Sidi Gazalba discusses the attitude of traditional Islamic teachers towards HSBI. ${ }^{31}$ The following quotation is of interest, because it discusses reactions to HSBI's use of drama as a forum for proselytizing:

It often happened that when HSBI took its proselytizing plays into villages, they would first approach a prominent ulama in the village to explain their intentions. Usually the ulama would deny them permission to perform, saying that forms of artistic activity were prohibited by Islamic law (haram). The young HSBI activists would then say that they would obey all the ulama's instructions after he himself had watched their performance. So a performance was then staged for this principal and honoured spectator's inspection. As the performance was based on the Islamic view of art, primarily meaning that it was a representation of Islamic moral values, the response from the ulama was often along the lines of 'If this is what you do, I have no objections at all. This is not haram. I support your way of teaching people about Islam, ${ }^{32}$

Experiences like this contributed to HSBI's enthusiasm for the development of Islamic art and literature as a forum for proselytizing, so that these forms would not become the exclusive preserve of groups they considered to be opposed to Islam. Clearly, the thinking here was to counter the cultural spirit of LEKRA, which was

31 In the preface to Pandangan Islam tenang kesenian, Sidi Gazalba explains that the book originated as a working paper for the Faculty of Islamic Studies in the Universiti Kebangsaan Malaysia. Apart from providing information for students, the book was intended as a response to questions raised in the academic community in 1976-1977 about Islamic views on art. Interesting in this context is that the Indonesian experience of the rise of Islamic genres in the arts in the 1960s via Muslim cultural organizations like HSBI, LESBUMI and others in confronting LEKRA inspired the Malaysian exploration of Islamic views about art in the 1970s. This adds a specific 'Islamic' dimension to the relationship of Indonesia being the 'exporter' of ideas to Malaysia, which Budiawan discusses in his contribution to this volume.

32 Peristiwa yang sering terjadi ketika HSBI memasuki desa-desa, membawa dramanya sebagai saluran dakwah adalah sebagai berikut. Mula-mula mereka datangi ulama yang terkenal di desa itu. Mereka sampaikanlah hasrat mereka. Biasanya ulama itu menolak. Karena kegiatan seni dipandangnya negatif, biasanya dihukumnya haram. Anak-anak HSBI akan menerima pandangan ulama itu setelah beliau mempersaksikan sendiri drama yang mereka bawakan. Setelah itu mereka akan patuhi segala arahan beliau. Maka sebagai penonton utama dan terhormat, ulama itu memperhatikan dengan saksama penyelenggaraan drama itu. Kerana HSBI membawakan pandangan Islam tentang kesenian, antara lain yang utama ialah pertunjukan karya itu mengandung nilai-nilai akhlaq Islam, maka sering sekali HSBI mendapat penilaian dari ulamaulama yang diundangnya menonton itu: 'Kalau begini anak-anak kerjakan, saya tidak keberatan sama sekali. Yang begini tidaklah haram. Saya menyokong cara dakwah kamu ini' (Sidi Gazalba 1977:73-4). 
often portrayed by the 'A' group (of NASAKOM) as atheistic, based on a denial of the existence of God.

In the early 1960s, rivalry between 'Islamic' and 'communist' groups was very overt, and the influence of LEKRA was accelerating in line with the growing strength of the PKI. HSBI, and later also LESBUMI and other Islamic cultural groups confronted this rivalry and the associated conflict openly, as can be seen in the text of Usmar Ismail's 1964 lecture to the employees of the Department of Foreign Affairs:

But LESBUMI regards a culture that espouses atheism or agnosticism as imperialist culture that clearly conflicts with the philosophical outlooks of the State and People of Indonesia as enshrined in the Pancasila. In Islamic law, this is a culture of heathenism. ${ }^{33}$

However, apart from the energy required to compete with LEKRA, HSBI also faced the challenge of dealing with dissent in the Islamic community itself over its approach to the modernization of Islamic art and culture, as Sidi Gazalba shows in his 1977 book discussed above. In the five years after its establishment, HSBI made little progress, and its expansion continued to be limited by a lack of funding from Islamic bodies for cultural activities.

In its attempts to modernize Indonesian Muslim attitudes towards the potential of literature and drama as proselytizing media, HSBI was a genuinely pioneering organization. To a large extent it was successful in changing attitudes, although it later faced the problem of how to raise the quality of its performances and to give them an appropriate Indonesian character and identity. This question of Indonesian character and identity related to the fact that HSBI's performances often drew on Arabic cultural settings (Nuhrison M. Nuh 1984:31). Its successes owed much to the institutional, and probably also financial, backing it received from the Department of Religion. Following its first national conference, it declared itself ready to serve as a Pusat Rohani (PUSROH, Islamic Spiritual Centre) for members of the Army, Navy, Air Force and Police, which helped to place it on a sound institutional footing. HSBI took note of the short-lived Council for the Indonesian Islamic Cultural Congress (BKKII, Badan Kongres Kebudajaan Islam Indonesia) (Hamka 1962:13; Amura 1966:7) which had been

33 Tetapi kebudajaan jang bernafaskan mengingkari adanja Tuhan atau menimbulkan keraguraguan adanja Tuhan, oleh Lesbumi pun dianggap sebagai kebudajaan imperialis jang terang2 bertentangan dengan filsafah Negara dan Rakjat Indonesia, Pantjasila. Malahan kebudajaan jang demikian didalam hukum Islam adalah kufur adanja (Usmar Ismail 1964a). 
established in 1954 as a rival body to the BMKN (Badan Musjawarah Kebudajaan Nasional, Council for Deliberations on National Culture) which organized the national cultural conferences, and saw this as a reminder that HSBI needed strong backing to survive and prosper. ${ }^{34}$

HSBI: ALLYING WITH LESBUMI TO PLANT THE SEEDS OF

MODERNIZATION IN ISLAMIC ART AND CULTURE

In Indonesia, Muslim artists do not enjoy favourable conditions or the patronage of the ulama. Many of them face restrictions and a range of problems, not only by outsiders but also by ulama who are hostile to them, yet artists play an important role in society and have useful meaning to their audiences. ${ }^{35}$

After its January 1961 National Conference, HSBI's future seemed assured. Internal conflicts over the modernization of art and culture among the umma proved to a large extent to be containable, especially after the December 1961 Deliberation of Islamic Artists and Cultural Figures that was jointly organized by HSBI and MASBI. Following this latter conference, any questions about the legitimacy or otherwise of an artistic activity according to Islamic law were referred to a set of edicts (fatwa) which the conference had issued. It also had a positive impact on Islamic artists and cultural figures outside HSBI, thus generating the sense of a broader Islamic cultural movement. The subsequent emergence of cultural organizations associated with Islamic political parties indicated that HSBI was no longer alone in its confrontations with LEKRA.

Three working papers were presented to the December 1961 Musjawarah Seniman Budayawan Islam: 1. Tindjauan kebudajaan dan kebudajaan Islam serta pertumbuhan di Indonesia (A review of culture and Islamic culture and their growth in Indonesia), presented by Sidi Gazalba B.A. representing the young generation; 2. Kebudajaan dan

34 The BKKII was an initiative of Hamka and his colleagues that was launched at the 1954 Congress on Indonesian Culture (Kongres Kebudajaan Indonesia) which was organized by BMKN. Hamka (1962:13) stated that the BKKII was a response to the rapid development of other cultural movements (referring to LEKRA) in the 1950s.

35 Di Indonesia seniman Muslim tidak mendapat kedudukan yang baik, serta dapat perlindungan dari para ahli-ahli agama, banyak para seniman Muslim, karena banyak rintangan serta banyak masalah-masalah yang harus dihadapi, bukan hanya dihadapi oleh orang luar saja tetapi juga para ulama memusuhinya, sedangkan peranan seniman punya arti yang penting di kalangan masyarakat, punya arti yang berguna di kalangan penggemar (Jassin 1983:88). 
kesenian menurut hukum Islam (Culture and art according to Islamic law), presented by $\mathrm{H}$. Abdullah bin Nuh representing the ulama; and 3. Mengembangkan kebudajaan dan kesenian menurut adjaran Islam (Developing culture and art according to Islamic teachings), presented by H. Moh. Saleh Suaidy representing the Ministry of Religion. The conference succeeded in drafting a resolution defining the position of Islam in relation to the 'Indonesian identity' that formed one of the principles of Manipol-USDEK, as Soekarno's 1959 formulation of political and ideological orthodoxy came to be known. ${ }^{36}$ In addition, it formulated the following principles and guidelines concerning art and Islam: 1. art is a legitimate activity according to Islamic law (halal); 2 . in pursuing artistic activities, there is a need to avoid actions that are haram; 3. in relation to sculpture, there are widespread concerns, because sculpture is susceptible to the sin of polytheism (kemusyrikan) (Sidi Gazlaba 1977:71-2; Amura 1962: 25-7). In essence, the conference determined that art was legitimate according to Islamic law. This then became the guiding principle that HSBI attempted to implement in its activities in the field of art and culture:

Armed with this determination by the ulama the way was open to HSBI to take on LEKRA and fortify Islamic youth against becoming prey to LEKRA, as well as providing opportunities for young Muslims to satisfy their artistic sensibilities. At that time there were four Islamic parties, each of which now moved quickly to form their own art institutes. ${ }^{37}$

The organization of the Musjawarah Seniman Budayawan Islam with support from the Department of Religion, and the edicts on religion and art that the conference issued, provided the impetus for greater cooperation between Muslim artists and cultural figures as well as between Muslim political parties and other Islamic organizations. As mentioned earlier, NU established LESBUMI, PERTI set up LEKSI, the PSII founded LAKSMI and Muhammadijah launched ISBM, to name a few. HSBI itself became an art and culture forum for activists and sympathizers of MASJUMI, the party

36 Kratz 1986:72. The principles summarized in the acronym USDEK were: UUD 1945 (the 1945 Constitution), Sosialisme à la Indonesia (Indonesian-style Socialism), Demokrasi Terpimpin (Guided Democracy), Ekonomi Terpimpin (Guided Economy) and Kepribadian Indonesia (Indonesian Identity).

37 Dengan bersenjatakan fatwa ulamak-ulamak itu terbukalah bagi HSBI kegiatan-kegiatan, baik menyaingi LEKRA, membentengi pemuda-pemuda Islam supaya jangan sampai menjadi mangsa LEKRA, menyediakan kesempatan bagi kaum muda untuk memuaskan rasa-seninya. Ketika itu ada empat parti Islam. Masing-masing parti tidak ragu lagi menubuhkan lembaga keseniannya sendiri (Sidi Gazalba 1977:72). 
that had been banned by Soekarno in August 1960. All of these organizations were attempting to present a different face of Islam in the field of art and culture. LESBUMI, for instance, differed from HSBI in that it was both a cultural movement and a political association, whereas HSBI remained an Islamic cultural organization that was not directly involved in politics.

HSBI's successful promotion of Islamic-based art and culture activities owed much to the role played by Junan Helmy Nasution, who was appointed as a new leader of the organization at the January 1961 National Conference. Replacing Nur Alian, a Ministry of Religion figure, Junan approached his role in a more proactive way, perhaps reflecting his military background. He was an Army captain who at the time was head of Bureau III of the Jakarta branch of the Army's Islamic Spiritual Centre (PUSROH Islam Angkatan Darat). Previously he was head of the Regional Executive of the Greater Jakarta HSBI, and was known for his prolific work in Islamic-inspired theatre and drama (Indonesia O'Galelano 1963:21-3). A sense of his contribution to HSBI is conveyed in the following comments by Indonesia O'Galelano:

Apart from his dedicated attention to administrative matters, Yunan's ${ }^{38}$ tenacity was evident in a performance of the story of the Birthday of the Prophet (Maulid Nabi) in the arena theatre of the Al-Azhar Mosque in Kebayoran Baru. The scale of this performance was unprecedented in the history of Indonesian drama, with an audience of around 30,000 people and 15 horses taking part in an exploration of statements by the Great Prophet and propagation of their significance for the life of our nation. And for the first time too, Yunan's HSBI compiled a recognized program of action for Islamic drama, which became a basis for activities that formed part of the struggle to intensify the propagation of Indonesian Islam. ${ }^{39}$

HBSI's change of leadership in December 1961 served to indicate that its institutional support came not only from the Department

38 Nasution's first name is spelt interchangeably as Junan and Yunan. Quotes follow the spelling used in each case.

39 Bukti dari kegigihan Yunan disamping tekun dibalik medja tulisnja, ialah pada pergelaran kissah Maulid Nabi dalam bentuk arena teater dihalaman mesdjid Agung 'Al-Azhar' Kebajoran Baru, dimana untuk pertama kalinja sedjarah drama Indonesia dapat memiliki, penonton sedjumlah k.1. 30.000 orang dan sedjumlah 15 ekor kuda digiring ketempat itu untuk disuruh berperan, dalam rangka menggali dan mensiarkan pernjataan Nabi Besar ini bagi kehidupan bangsa kita. Dan untuk pertama kali pulalah - H.S.B.I. Yunan menjusun chittah seni drama Islam jang terkenal, jang mendjadi dasar berpidjak dan berdjoang untuk intensifikasi da'wah Islam Indonesia (Indonesia O'Galelano 1963:22-3). 
of Religion, but also from the military. Under Junan's leadership the organization underwent a period of rapid development. Within 18 months or so performances were staged in a number of cities and towns all over Java and also in South Sumatra. Plans were also underway for performance troupes to visit provinces in Kaliman$\tan$, Sulawesi and West Irian, making use of the bureaucratic structures of the Department of Religion and the Army to promote the mental and spiritual development of the umma throughout Indonesia. To this point, drama was the 'outstanding product' in HSBI's activities in the field of art and culture.

The appearance of Gema Islam, a journal of Islamic culture and knowledge, in early 1962, soon after HSBI's national conference in January 1961, was another clear indication of military support for the organization. ${ }^{40}$ Its publication was a purely military initiative, in the framework of the 'Planned Universal Development' (Pembangunan Semesta Berentjana) program, especially in relation to mental and spiritual development. In the interests of this program, General Abdul Haris Nasution assigned three middle-ranking officers, Brigadier General Soedirman, Lieutenant Colonel M. Rowi and Lieutenant Colonel Moh. Isa Edris, to non-military duties as executors, managers, and members of the editorial board of Gema Islam. The difficulties which HSBI had always experienced financially were alleviated with the publication of the journal, allowing other cultural activities to proceed more smoothly and regularly than in the past.

The involvement of these three middle-ranking officers in the management of Gema Islam, along with the expansion of HSBI throughout Java and beyond under Junan's leadership seems to have been the impetus for LEKRA and the PKI's attention to a cultural movement dedicated to 'soldiers' (pradjurit). It was not until 1964, in his speech to LEKRA's National Conference on Revolutionary Art and Literature (KSSR, Konfernas Sastra dan Seni Revolusioner), that Aidit extended the designation of art for 'workers' (buruh) and 'peasants' (tani) to include 'soldiers', bringing Indonesian terminology and practice into line with the Maoist doctrine

40 The editorial in Gema Islam's inaugural issue stated that the magazine was published as a cooperative venture between the military, the Central Islamic Library Institute (Jajasan Perpustakaan Islam Pusat) and the community: 'The composition of the editorial board and contributors reflects the close cooperation that exists between ourselves, military figures, members of society, and the broader community itself. We have joined together in the interests of our nation and the state we are constructing, and above all else, "in the interests of Islam, our guide in life and death".' ('Dalam susunan redaksi dan para pembantu terlihatlah gambaran kerdjasama jang erat diantara kami, orang2 militer, anak masjarakat, dengan masjarakat itu sendiri. Tergabung djadi satu untuk kepentingan bangsa dan negara jang sedang kita bangunkan, dan diatas dari itu semuanja "Bagi kepentingan agama Islam, pegangan kita dalam hidup dan mati kita”.') See 'Pembuka kata' Gema Islam 1-1 (15 January 1962):3. 
of revolutionary art and literature. According to Aidit, the Indonesian Armed Forces was: 1) anti-fascist, democratic, anti-imperialist and committed to socialism; 2) a weapon in the great struggle of the New Emerging Forces (NEFO) against the Old Established Forces (OLDEFO) $;{ }^{41}$ and 3 ) a means of defending the integrity of the territory and unity of the Indonesian nation. For that reason, he said, 'revolutionary art and literature must not only be dedicated to the workers and peasants, but also to the soldiers'.$^{42}$ In celebrations marking its seventh anniversary on 24 September 1963 and the announcement of its forthcoming Second National Conference (Muktamar II) the following December, HSBI reaffirmed its institutional status. In his Tudjuh tahun H.S.B.I. 24 Sept. 1956 - 24 Sept. 1963 (Seven years of HSBI, 24 Sept. 1956 - 24 Sept. 1963) Junan confirmed that HSBI was ready to serve as a tool of the Department of Religion and an Islamic spiritual centre for all branches of the Armed Forces (Junan Nasution 1963). In the same document he also noted that as of 1963 HSBI had 80 branches throughout Indonesia.

Junan stated there was a need for a restructuring of the organization's institutional basis. There was to be a clear division of tasks between two separate bodies, the first comprising 'arts workers' ('karyawan seniman pekerdja') whom Junan described as the manual labourers, which would be delegated to the HSBI Central Leadership (Pimpinan Pusat HSBI). The second body was the 'arts and culture thinkers' ("karyawan seniman budajawan pemikir'), who would formulate the blueprints, the sketches for the Islamic art that was to be given form by others which would be delegated to MASBI. These two bodies together formed the structural basis of HSBI. As Junan proposed, 'A "building" cannot be constructed only by manual labourers without engineers, and vice versa' ('Tidak mungkin ada "bangunan" hanja dengan kuli pengangkut batu belaka tanpa insinjur dan sebaliknja'). In that same year, 1963, MASBI, whose members now numbered 30 ulama, 10 academics, five religious leaders (zuama) and 20 Islamic artists from different branches of the arts held its own conference in Jakarta. ${ }^{43}$ This conference gave its support to the restructuring of HSBI's organizational basis.

It was thus primarily through literature and drama that HSBI attempted to plant the seeds of modernization in Islamic art and culture. Initially, this was seen as a way of countering the devel-

41 On NEFO and OLDEFO see Weatherbee 1966.

42 ' [s] astra dan seni revolusioner tidak hanja harus diabdikan kepada buruh dan tani, tetapi djuga kepada pradjurit'. (Aidit 1964:30-1, italics in the original.)

43 The majority of MASBI's members were men. One of the women members of the Council was Aisjah Amini, a prominent Islamic political figure of the time. See www.tokohindonesia. com/ensiklopedi/a/aisyah-aminy/biografi/bio06.shtml. 
opment of LEKRA, and, in Sidi Gazalba's words, fortifying Islamic youth against 'falling prey' to LEKRA. Yet the challenges faced by HSBI came not only from outside the world of Islam but also from within the umma itself, specifically in relation to viewpoints that regarded all artistic activity as haram. Its efforts to introduce new forms of literature and drama as proselytizing media also faced the problem of the traditional Islamic community's lack of familiarity with these art forms. The involvement of women in its performances (women appeared alongside male performers on stage) was also something traditional Muslim circles found hard to accept. Through the edicts solicited from the 'elders' (kaum tua) during the 1961 Musjawarah Seniman Budajawan Islam, HSBI attempted to problematize the relationship between religion and modern art and culture in Indonesia. Its efforts subsequently led to similar actions by groups of Islamic artists and cultural figures in other organizations, such as LESBUMI in relation to NU.

The role that LESBUMI, under the influence of Djamaluddin Malik, Usmar Ismail and Asrul Sani, played within NU inspired HSBI to take further steps towards the modernization of Islamic art and culture in Indonesia. For example, members of the Arts Study Club (ASC), a body founded by HSBI, organized a discussion of Asrul Sani's film Titian serambut dibelah tudjuh (The passage), which took place at the Army Islamic Spiritual Centre on 18 November 1962. Discussions like this were seen as a way of contributing to the development of Indonesian film, particularly in relation to thinking about the future production of Islamic-inspired films (Sanusi Hasan 1963:25-6).

It appears that both HSBI and LESBUMI aspired to the creation of an 'Islam with a modern culture'. Yet their efforts to modernize Indonesian Islamic art and culture at this time coincided with a political situation that was approaching a climactic end. In his Independence Day address of 1964, Soekarno had declared 'a year of living dangerously' (tahun vivere pericoloso). Just how dangerous it was to be only became clear a little over one year later.

CONCLUSION; THE END OF THE DREAM OF THE RESURGENCE OF ASIAAFRICA ISLAM

The chapter on Indonesia which Soekarno had been instrumental in having added to the Indonesian translation of Stoddard's The new world of Islam dealt with Indonesian Islam in the period between 1900 and 1920, showing that along with Turkey, Egypt, Pal- 
estine and India, Indonesia had been one of the centres of Islamic renaissance and revival in the Asia-Africa world. It demonstrated the significance of Indonesia, a nation whose population was predominantly Muslim, to the rise of Asia-Africa. At the same time, it informed the Indonesian umma about their own past, as they took part in revolution and explored the spirit of Islamic struggle in other parts of the world.

The readers of the Indonesian translation of Stoddard's book were called upon to place themselves in the world of the early twentieth century, the years following the First World War. They did not find any discussion in the book of the period in which the book was translated, but this was something that they had experienced and witnessed for themselves. One after another, in the years following Indonesian independence in 1945, Islamic nations or nations with majority Islamic populations in the Asia-Africa region had gained their own sovereignty and independence. ${ }^{44}$ In a period of less than 50 years colonial oppression and the formal institution of colonialism had disappeared from the Islamic world, a startling experience of freedom that had been felt by all the peoples of the Asia-Africa region. The question remained, however, of how these newly independent nations with majority Islamic populations viewed colonialism in the broader sense that Soekarno had termed NEKOLIM (neo-colonialism and imperialism).

In contrast to the experience of other newly independent nations in the Asia-Africa region, Indonesian government policy in the period between 1959 and 1965 attempted to create a political, social and cultural life based on the confluence of nationalism, Islam, and Marxism, building on the ideas that Soekarno had first enunciated in the 1920s (Sukarno 1964:1-23). Just as the unity of these three forces had been instrumental in destroying colonialism in Indonesia in the pre-independence period, said Soekarno, so too would they destroy the forces of NEKOLIM on the international level in the years following independence.

The organization of the first KIAA in Indonesia in 1965 was an opportunity for Soekarno to demonstrate that Indonesia, the country with the largest Islamic population in the Asia-Africa region, was experiencing its own resurgence. He was thoroughly convinced that Islam represented a mighty wave that could be a revolutionary

44 Mohammad Natsir 1982:21-2. Natsir lists the following Asia-Africa countries that gained independence in the period between 1945 and 1965: Indonesia dan Iraq (1945), Syria (1946), India and the Islamic Republic of Pakistan (1947), Lybia (1952), Sudan (1955), Morocco (1956), Malaya and Tunisia (1957), Guinea and Mauritania (1958), Cameroon, Central African Republic, Chad, Dahomey, Ivory Coast, Mali, Niger, Nigeria, Senegal, Togo, Upper Volta and Somalia (1960), Algeria (1962), Malaya and North Kalimantan as Malaysia (1963), Gambia (1965). 
force to crush the power of NEKOLIM, a lesson he drew from the spirit of Jamaluddin al-Afghani and Syaikh Muhammad Abduh. In the mass meeting of the KIAA in the Gelora Bung Karno stadium, watched by an audience of around 110,000 people, the conference bestowed on Soekarno the title of 'Hero of Islam and Freedom' (Pahlawan Islam dan Kemerdekaan) (Rosihan Anwar 1965:4). The countries of Islam were entrusting the future of their religion to the political path that Soekarno had trod.

The tragedy was that Soekarno's conviction that the unity of these three forces could be realized and maintained proved in the end to be misplaced. In this respect, Stoddard's predictions were prescient, especially where the dangers Bolshevism posed for both the Western and Eastern worlds were concerned. 'Certainly', Stoddard wrote, 'any extensive spread of Bolshevism in the East would be a terrible misfortune both for the Orient and for the world at large. ${ }^{\prime 4}$ Rather than proving Stoddard wrong, Soekarno demonstated the truth of what Stoddard had predicted.

Translated from Indonesian by Keith Foulcher

\section{REFERENCES}

Abdul Haris Nasution

1962 'Sambutan M.K.N./KASAD Djenderal A.H. Nasution', Gema Islam 1-1 (15 January):4.

Abrar Yusra (ed.)

Otobiografi A.A. Navis, satiris dan suara kritis dari daerah. Jakarta: Gramedia Pustaka Utama.

Aidit, D.N.

1964 Tentang sastra dan seni; Dengan sastra dan seni jang berkepribadian nasional mengabdi buruh, tani dan pradjurit. Djakarta: Jajasan Pembaruan.

Amura (Abdul Muin Rafi'ah Ali)

1962 'Musjawarah besar seniman dan kebudajaan Islam', Gema Islam 1-1 (15 January):25-7.

1964 'Dari tjelah2 Muktamar HSBI', Gema Islam 3-46 (15 January):18-20.

1966 'Sepuluh tahun kebangkitan gerakan seni budaja Islam', Gema Islam 5-83 (15 September):7-8. 
Choirotun Chisaan

2008 LESBUMI strategi politik kebudayaan. Yogyakarta: LKIS.

Goenawan Mohamad

1969 'Posisi sastra keagamaan kita dewasa ini' in: Satyagraha Hoerip (ed.), Antologi esei tentang persoalan2 sastra. Djakarta: PT Sinar Kasih.

1988 'Peristiwa "Manikebu"; Kesusastraan Indonesia dan politik di tahun 1960an', Tempo (21 May).

Hamka (Haji Abdul Malik Karim Amrullah)

1962

“"Kebudajaan Islam adalah mazhar dari tauhid dan taqwa"; Sambutan Ketua MASBI Dr. Hamka pada malam penutup musyawarah HSBI tgl 15-17 Desember 1961 di Djakarta', Gema Islam 1-1 (15 January):11-4.

Indonesia O'Galelano

1963

'Tokoh pentas Islam; Yunan Helmy Nasution', Gema Islam 2-35 (1 July):21-3.

Jassin, H.B.

1983 'Seniman Islam di tengah masyarakat modern', in: H.B. Jassin (ed.) Sastra Indonesia sebagai warga sastra dunia dan karangan-karangan lain. Jakarta: Gramedia.

Junan Helmy Nasution

1963 'Tudjuh tahun H.S.B.I. 24 Sept. 1956-24 Sept 1963', Gema Islam 2-40 (15 September):20-1.

Kratz, E.U.

1986 'Islamic attitudes toward modern Indonesian literature' in:

C.D. Grijns and S.O. Robson (eds), Cultural contact and textual interpretation; Papers from the fourth European Colloquium on Malay and Indonesian Studies, held in Leiden 1983, pp. 60-93. Dordrecht: Foris. [KITLV, Verhandelingen 115.]

Kusni, J.J.

2005

Di tengah pergolakan; Turba LEKRA di Klaten. Yogyakarta: Penerbit Ombak.

Masdar F. Mas'udi and Syafiq Hasyim

1998

'K.H. Mohammad Iljas; Pengembangan Kementerian Agama' in: Azra, Azyumardi and Saiful Umam (eds), Menteri-menteri Agama RI: biografi sosial politik. Jakarta: Badan Litbang Agama Departemen Agama RI dan PPIM IAIN Jakarta.

Masri, S.

1964

‘4 Pertanjaan utk Usmar Ismail’, Bintang Timur(16 August). 
Misbach Yusa Biran

1990 'Perkenalan selintas mengenai perkembangan film di Indonesia'. Paper prepared for Asia University, Tokyo.

2008 Kenang-kenangan orang bandel. Depok: Komunitas Bambu.

Mohammad Natsir

1982 'World of Islam festival dalam perspektif sejarah' in: M. Natsir (ed.), Dunia Islam dari masa ke masa. Jakarta: Panji Masyarakat.

Nuhrison M. Nuh

1984

Himpunan Seni Budaya Islam (Sejarah dan peranannya sebagai media dakwah). Jakarta: Proyek Penelitian Keagamaan, Badan Penelitian dan Pengembangan Agama.

Rosihan Anwar, (al-Bahist)

1964a [under pseudonym al-Bahist] 'Dari KIAA hingga HMI turun kedesa', Gema Islam 3-49 (1 May):4-6.

1964b [under pseudonym al-Bahist] 'Dari serangan terhadap LESBUMI hingga soal rajuan', Gema Islam 3-52 (15 May):4-5.

1964c [under pseudonym al-Bahist] 'Dari mari kita sukseskan KIAA hingga Sunan Giri', Gema Islam 3-51 (1 June):4-5.

1965 [under pseudonym al-Bahist] 'Kronik komentar Islam; Dari keputusan2 KIAA hingga artinja bagi kita', Gema Islam 4-70 (15 March):4-6.

2006 Sukarno, tentara, PKI; Segitiga kekuasaan sebelum prahara politik 1961-1965. Jakarta: Yayasan Obor Indonesia.

Rusjdi

1965 'Mengikuti diskusi kebudajaan untuk K.I.A.A. di Tjipajung'. Gema Islam 4-68 (15 February):31-2.

Saifuddin Zuhri

$1981 \quad$ Sejarah kebangkitan Islam dan perkembangannya di Indonesia.

Bandung: al-Ma'arif.

Sanusi Hasan

1963

'Titian serambut dibelah tudjuh didepan Arts Study Club HSBI', Gema Islam 2-24 (15 January):25-6.

Sidi Gazalba

1977 Pandangan Islam tentang kesenian. Kuala Lumpur: Pustaka Antara.

Stoddard, Lothrop

1920 The rising tide of color against white world-supremacy. New York:

C. Scribner's Sons. 
The new world of Islam. London: Chapman and Hall.

$1966 \mathrm{a}$ Dunia baru Islam. Djakarta: Panitia Penerbit.

$1966 \mathrm{~b}$ Pasang naik kulit berwarna. Djakarta: Panitia Penerbit.

Sukarno

1964

Dibawah bendera revolusi, Djilid I. Djakarta: Panitya Penerbit Dibawah Bendera Revolusi.

1965 Dibawah bendera revolusi, Djilid II. Djakarta: Panitya Penerbit Dibawah Bendera Revolusi.

Usmar Ismail

$1964 \mathrm{a}$

'Tjeramah Ketua I Lembaga Seniman Budajawan Muslimin Indonesia, Sdr. H. Usmar Ismail dihadapan S.S. Deparlu Tanggal 7 Agustus 1964', Duta Masjarakat (23 August).

1964b 'Surat orang budaja', Duta Masjarakat (30 August).

1966 'Kisah putih duka tjerita sebuah musjawarah', Abad Musli$\min$ 2-29 (June).

Weatherbee, Donald E.

1966 Ideology in Indonesia; Sukarno's Indonesian revolution. Michigan: Yale University.

Zaini

1957

Almanak seni. Djakarta: BMKN. 